\title{
UN SINGULAR EJEMPLO DE PIEDAD MARIANA. NOTAS EN TORNO A UNA PINTURA \\ DE LA VIRGEN DE GUADALUPE
}

José Guadalupe Victoria

\section{Introducción}

La historiografía acerca de la pintura novohispana se ha acrecentado considerablemente en los últimos veinte años. ${ }^{1}$ Estudios generales, monográficos, catálogos y artículos de divulgación muestran que, contrariamente a lo que durante mucho tiempo se sostuvo, la pintura creada en el virreinato de la Nueva España presenta algunos rasgos muy distintos de la que se produjo en la metrópoli y en otros virreinatos americanos, verbigracia el del Perú o el de la Nueva Granada. Sin embargo, cabe señalar que, por ahora, no se cuenta aún con una obra general sobre esa expresión plástica en la que se recojan las novedades en la producción historiográfica a que aludimos.

Ahora bien, uno de los rasgos más novedosos de la producción pictórica virreinal de todo el continente se refiere a la iconografía que, si bien deriva en gran medida de modelos europeos, desde tiempos muy tempranos fue modificada sensiblemente por los artistas locales. Además, puede afirmarse que el desartollo histórico propio de los territorios americanos favoreció el surgimiento de una iconografía local que sólo conocemos parcialmente. $^{2}$

En el caso del virreinato de la Nueva España fueron muy significativos dos cultos: el de Santa Rosa de Lima - primera santa americanay el de Nuestra Señora de Guadalupe; ambos favorecieron el surgimiento y desarrollo de una iconografía que invadió la arquitectura, la escultura $y$, sobre todo, la pintura. ${ }^{3}$

Por lo que se refiere al segundo de esos temas, una muestra de su rique-

1 José Guadalupe Victoria y María Teresa Velasco, Bibliografía de Arte Novohispano. 1.521-1985. En prensa.

2 Así lo prueban los trabajos de Francisco Stastny y Teresa Gisbert. Vid. Hand Book of Latin American Art. Manual de Arte Latinoamericano. A Bibliographic Compilation, vol. II, Art of the Colonial Poriod, Santa Bárbara California-Oxford, England, 1986, 540 p.

3 Consúltense los estudios sobre ambos temas realizados por Elisa Vargas Lugo, registrados por José Guadalupe Victoria y María Teresa Velasco, op. cit. 
za iconográfica pudo verse en la exposición sobre imágenes guadalupanas celebrada en la ciudad de México, de noviembre de 1987 a marzo de 1988. ${ }^{4}$ Entre los cuadros expuestos figuró el que es objeto de estas líneas. Se trata de una representación de la Virgen de Guadalupe con las cuatro apariciones y los cuatro baluartes de México (óleo sobre tela de $1.46 \times$ $1.20 \mathrm{~m})$ y que forma parte del acervo de la Pinacoteca Virreinal de San Diego.5 (Fig. 1).

De entrada hay que decir que este cuadro no es una de tantas representaciones de la Virgen de Guadalupe. Por el título que le hemos dado, salta a la vista que estamos ante una compleja alegoría mariana y más específicamente guadalupana. ¿En qué reside la complejidad y por ende la sigularidad de este cuadro? ¿Por qué los distintos especialistas del tema no habían prestado su atención a esta alegórica "visión" de la Virgen Morena? Vale la pena recordar, en sus lineas generales, cuál fue el desarrollo de la iconografía guadalupana.

Según Elisa Vargas Lugo - hoy por hoy una de las más grandes conocedoras de la iconografía guadalupana-, con base en las observaciones de Francisco de la Maza y las suyas propias, el culto a la Virgen del Tepeyac no se desarrolló sino a partir de mediados del siglo XVII. ${ }^{6}$ Aparte del lienzo original no se conocen representaciones que daten del siglo XVI; precisamente por eso resultó sumamente reveladora la exhibición -en la muestra citada - del lienzo pintado por Baltazar de Echave Orio, en 1606, que no incluye las apariciones. (Fig. 2). Otras imágenes guadalupanas significativas debido a su cronología son: la pintura de Lorenzo Delapyedra, fechada en 1625, conservada en la iglesia del Santo Desierto de San Luis Potosí. Contemporáneo de esta pintura es el mural atribuido al padre Salguero y que se conserva en el convento agustino de Yuririapúndaro, Gto. ${ }^{7}$ Sin embargo, puede afirmarse que fue Juan Correa (ca. 1666 - ca.1714) uno de los primeros pintores que con mayor intensidad representaron a la Virgen del Tepeyac. Otros pintores contemporáneos suyos - Villalpando, por ejemplo- también elaboraron importantes cuadros con tema guadalupano. Ya en el siglo XVIII hubo artífices - entre quienes destaca sobremanera Miguel Cabrera- que inundaron los altares

4 Imágenes Guadalupanas. Cuatro Siglos, México, Centro Cultural Arte Contemporáneo, 1987.

5 El cuadro aparece reproducido en la p. 225 del católogo citado en la nota anterior.

- Elisa Vargas Lugo, "Iconología Guadalupana", Imágenes Guadalupanas. Cuatro Siglos, p. 57.

7 Ibidem, p. 76. 
de iglesias, muros de conventos y casas particulares, con representaciones de esa imagen. ${ }^{8}$

No obstante gran parte de dicha producción es anónima; y en ella cabe incluir el bellísimo cuadro que llama nuestra atención. Aunque no conozcamos el nombre de su autor, ni cuando lo pintó, es un hecho que esta obra basta por sí sola para darle un lugar destacado en la producción pictórica dieciochesca. Importancia que se acrecienta al analizar la iconografía plasmada en el lienzo, pues no cabe duda que resulta una clara representación de la manera de pensar y de sentir propia de los criollos novohispanos de fines del siglo XVIII; especialmente de los de la ciudad de México.

\section{Iconografia e iconología de esta obra}

Como es conocido de todos, la imagen original de la guadalupana no incluye la representación de las escenas alusivas a las cuatro apariciones. $\mathrm{Al}$ parecer también fue Juan Correa uno de los primeros pintores que las incorporaron en sus representaciones, junto con otros elementos iconográficos altamente significativos y que reforzaban esa iconografía; por ejemplo las orlas de flores, especialmente rosas y grupos de angelillos. (Fig. 3).

Otro elemento novedoso de la iconografía guadalupana es la escena que ha sido considerada como la Quinta Aparición. O sea el momento en que la Virgen se apareció a Juan Bernardino, tío de Juan Diego, para manifestarle su deseo de llamarse Santa Maria de Guadalupe. ${ }^{10}$

También muy importante y novedosa es la inclusión del paisaje del santuario; al grado de que puede hacerse un estudio de las representaciones que datan del siglo XVII y otro del mismo, tal como era en el siglo XVIII. ${ }^{11}$ Por significativo merece mencionarse el cuadro pintado por Juan de Villegas en el momento en que el santuario dieciochesco -obra de Pedro de Arrieta - se encontraba en construcción. (Fig. 4).

Andando el tiempo, la iconografía guadalupana fue enriquecida con otros motivos marianos que llegaron a constituir complejas alegorias; en

8 Ibidem, p. 100, passim.

9 Ibídem, pp. 81-86.

10 Ibídem, p. 86.

11 José Guadalupe Victoria, "El santuario de Nuestra Señora de Guadalupe de México en la plástica novohispana". En elaboración. 
la que se pone de manifiesto la imaginación y audacia de los artífices novohispanos quienes, es muy difícil precisarlo, no sabemos si motu proprio o por sugerencia de los patronos para quienes trabajaban, plasmaron motivos iconográficos que podrían ser considerados como heréticos. Sin embargo, es evidente también que las autoridades religiosas del virreinato las "ignoraron", sino es que las "aprobaron" y, lo que es más, las propagaron; sirva de ejemplo la variante iconografía de San Lucas pintando a la Guadalupana, que luego derivó en Cristo pintando a la Guadalupana y -rasgo de mayor audacia-Dios Padre y el Espiritu Santo pintando a la Guadalupana (iii). ${ }^{12}$ Todo, al parecer, pareció lícito a los criollos novohispanos con tal de mostrar que esta tierra y sus hombres eran muy distintos a los de la Vieja España.

El cuadro que estudiamos aquí presenta los rasgos generales de las imágenes guadalupanas, en cuanto a que reproduce la figura principal apegada al lienzo original, por más que el pintor le haya dado al rostro de la Virgen un tratamiento "personal"; pues lo alargó y el arco de las cejas lo hizo mucho más pronunciado y la nariz resulta muy rectilínea. Otros rasgos de la Virgen y el angelillo que la carga se apegaron también al original. Las escenas que representan las cuatro apariciones están colocadas como es usual, en las esquinas del lienzo y unidas al riquísimo marco ovalado --imitando madera - que sigue el contorno de la mandorla en la que se proyectan los rayos. Acentúan la riqueza del marco los roleos que en él se entrelazan, terminados en hojas de acanto pero tratados como si fueran rocailles.

Estos roleos se interrumpen para "abrazar" los medallones de las apariciones y, a la mitad del lienzo, en sentido horizontal, generando dos óva. los donde hay sendas imágenes marianas; en sentido vertical se unen dos espacios apaisados en los que el pintor plasmó otra imagen mariana -en la parte superior- y la representación del santuario. (Figs. 5 y 6 ).

En el espacio irregular que queda entre la mandorla y el marco, tratado como espesas nubes, el artífice dispuso una cinta - a manera de listónen la que, de trecho en trecho, colocó elegantes ramilletes de flores, algu-

12 Algunas de estas representaciones aparecen reproducidas en las siguientes obras: Francisco de la Maza, El guadalupanismo mexicano, México; Porrúa y Obregón, 1953, láminas 8 y 9. Album conmemorativo del 450 aniversario de las Apariciones de Nuestra Señora de Guadalupe, México, Ediciones Buena Nueva, 1981, láminas 85, 86 y 119. Imágenes Guadalupanas. Cuatrocientos Años, láminas 86, 87,88 y 89. Véase también: José Guadalupe Victoria, "Iconografía de una portada barroca en Zacatecas". Un hombre, un destino y un lugar. Homenaje a Federico Sescosse. En prensa. 
nas de las cuales pueden identificarse como rosas y claveles; en los extremos superiores dispuso auténticos manojos de rosas.

El resultado fue una recargada composición cuyo barroquismo intensifica el colorido del cuadro, siendo luminoso en el gran óvalo que aloja a la Virgen y claroscurista en el contorno del marco y las escenas secundarias.

Ahora bien, tal como señalamos al inicio de este artículo, la pintura resulta singular en el contexto de las representaciones guadalupanas. Singularidad debida a la inclusión de las tres escenas dispuestas en el vértice superior y en sus extremos, en íntima relación con la escena de la parte media inferior, o sea la que representa al santuario. Porque convengamos en que, aun con toda su riqueza decorativa y colorística, si el cuadro reprodujera la imagen de la Virgen con las cuatro apariciones, y aun el paisaje del santuario, no pasaría de ser una de tantas imágenes dentro de la enorme producción guadalupana. Pero lo notable e insólito es que el artista lo asoció a otras devociones marianas, a saber: Nuestra Señora de la Piedad -en el vértice superior-, Nuestra Señora de los Remedios, en el lado izquierdo, y Nuestra Señora de la Bala, en el extremo contrario.

Con toda intención es hasta este momento cuando señalamos la identidad de estas imágenes, pues dan pauta para referinos a un tema ya estudiado en otra ocasión. ${ }^{13}$ En ese trabajo hacemos notar cómo la idea de poner a las ciudades y pueblos bajo el patrocinio de un santo o de la Virgen, en alguna de sus advocaciones, fue práctica frecuente en Occidente desde tiempos antiguos. La ciudad de México no resultó una excepción, y aunque mucho después de concluida la Conquista contó con varios santos patronos, es significativo que a partir de mediados del siglo XVII la Guadalupana fuera considerada como la patrona más importante. Patronazgo que con el tiempo - ya en el siglo XVIII - se acentuaría al asociarla a otras devociones marianas - Virgen de los Remedios, Virgen de la Piedad y Virgen de la Bala- originando y fortaleciendo la idea de los cuatro baluaries de México, según lo entendió Manuel Fernández de Echeverría y Veytia. ${ }^{14}$

13 José Guadalupe Victoria, "De blasones y baluartes mexicanos". Estudios. Filosofía, historia, letras, n. 11, pp. 127-135. México, Instituto Tecnológico Autónomo de México, Invierno 1987.

14 Mariano Fernández de Echeverría y Veytia, Baluartes de México. Descripción Histórica de las cuatro milagrosas imágenes de Nuestra Señora que se veneran en la muy noble, leal, e imperial ciudad de México, capital de la Nueva España, a los cuatro vientos principales, en sus extramuros, y de sus magníficos santuarios, con 
México gozaba de manera especial de la protección de María -en su advocación de Guadalupe- puesto que ella misma se apareció en tierras del antiguo Anáhuac. ¿Qué prueba más irrefutable de querer proteger a México? Siempre que la ciudad padeció alguna desgracia -inundaciones, terremotos y epidemias - la Guadalupana brindó consuelo a sus hijos mexicanos. Por ejemplo durante la peste de matlazáhuatl que asoló durante dos años a la ciudad (1736-1738) y que diezmó como nunca a la población. Ningún esfuerzo humano fue suficiente para calmar lo que fue visto como castigo de Dios. Por eso se imploró la ayuda de la Virgen de Guadalupe, considerada escudo de armas de México.

La asociación de la Guadalupana con la Virgen de los Remedios, la de la Piedad y la de la Bala, constituye uno de los temas más apasionan. tes de la historia y del arte novohispano. Puesto que cada una de esas imágenes recibía culto en un santuario dedicado especialmente a ellas; situados, además, en los cuatro puntos cardinales, aunque no del todo equidistantes. En ese sentido eran, sin duda alguna, baluartes de fe y las imágenes ahí veneradas constituían los blasones de la ciudad.

Sorprende y conmueve, a la vez, el esfuerzo de los criollos novohispanos por probar tal idea, que si bien hasta hace poco sólo se conocía en la literatura, también pasó a la plástica, siendo el lienzo que estudiamos uno de los primeros ejemplos conocidos actualmente.

Vale la pena mencionar algunas particularidades de los baluartes de México —o sea los cuatro santuarios - antes de referirnos a las imágenes representadas en el lienzo que estudiamos aquí, para finalmente referirnos a su posible significado como totalidad.

El origen del santuario de los Remedios reconoce como antecedente el encuentro milagroso de la Virgen - una escultura de bulto- en las faldas del cerro de Totoltepec (hoy en día jurisdicción de San Bartolo Naucalpan, Méx. y en su tiempo dependiente de Tacuba). Dicha imagen, según la tradición, fue traída por uno de los conquistadores, quien la extravió durante la huída de la llamada Noche Triste, y más tarde la encontró un indígena de nombre Juan. Mediante una serie de "desapariciones voluntarias" manifestó su voluntad de que le erigieran ahí un santuario. Mismo que se construyó en el sitio donde se levanta el actual, que data del siglo XVII, aunque con sensibles modificaciones en los siglos posteriores.

otras particularidades, por el Lic. D., obra póstuma dada a la luz por el R.P. Fr. Antonio María de San José, carmelita descalzo, México, Imprenta de Alejandro Valdés, 1820,89 . p. 
La imagen es una pequeña estatuilla de madera, tardo gótica, denominada, junto con otras, "de las conquistadoras" porque se supone fueron traídas por los soldados entre sus pinguies pertenencias. Es posible que desde un primer momento "se le vistiera" con ricos ropajes y la adornaron con sinnúmero de joyas; tal como la representan las más tempranas pinturas que de ella se conservan y según la describen algunos escritores de la época.

El santuario dedicado a Nuestra Señora de la Piedad -hoy en día desaparecido- fue fundado por los religiosos dominicos, quienes desde fines del siglo XVI deseaban tener un colegio en México, al sur. Ahí recibió culto una pintura traída desde Roma (inconclusa según la tradición), la cual, tras penosos percances ocurridos en "la mar océano", se manifestó como aún se le ve; hecho que de inmediato fue considerado milagroso y signo para que se iniciara la construcción del santuario que dio nombre a un río y a una calzada; el cual consagraron solemnemente en 1623. Pronto atrajo la atención de los habitantes de México, "siendo este uno de los santuarios más frecuentados especialmente los sábados de Cuaresma". ${ }^{15}$

Un desagradable incidente cotidiano ocurrido en un pueblo de los alrededores de México - la tradición señala que fue Iztapalapa - originó que una escultura recibiera culto en la iglesia de San Lázaro, al poniente de la ciudad, anexa al convento-hospital que administraban los religiosos de San Juan de Dios. La piadosa tradición indica que cierto día "un agraviado esposo trató de asesinar a su infiel cónyuge, quien acogióse a la protección de una imagen de María - no se especifica de qué advocación-, siendo ésta el blanco del disparo hecho por el engañado esposo. A partir de ese momento la imagen empezó a recibir culto bajo el nombre de Nuestra Señora de la Bala" ${ }^{16}$ Ahí recibía particular devoción "de todos... y son muchos los beneficios, que hace Dios por medio de esta Santa Imagen". ${ }^{17}$

Desgraciadamente, a raíz de la Nacionalización de los Bienes del Clero

15 Francisco de Florencia, S. J., Zodiaco Mariano, en que el sol de justicia Christo con la salud en las alas visita como signos, y casas propias para beneficio de los hombres, los templos, y lugares dedicados a los cultos de su SS. Madre por medio de las más célebres, y milagrosas imágenes de la misma señora, que se veneran en esta América Septentrional, y reynos de la nueva España, obra póstuma de el Padre Francisco de Florencia, de la Compañía de Jesús, reducida a compendio, y en gran parte añadida por el P. Juan Antonio de Oviedo de la misma Compañía. .., México, Nueva Imprenta del Real y más Antiguo Colegio de San Ildefonso, 1755, p. 82-83.

16 José Guadalupe Victoria, op. cit.

17 Francisco de Florencia, S. J., op. cit. 
(1859), el convento fue vendido, perdiéndose el rico patrimonio artístico que atesoraba. ${ }^{18}$ Ignoramos la suerte que tuvo la imagen de Nuestra Senora de la Bala. Tampoco conocemos imágenes - pinturas o esculturasde ella; por lo cual su representación en el lienzo guadalupano que llama nuestra atención es por đemás significativa.

En cuanto al santuario guadalupano - al norte de la capital- sus orígenes han sido estudiados desde distintos puntos de vista. No obstante, las investigaciones de Francisco de la Maza y Edmundo O'Gorman ${ }^{19}$ acerca del culto prueban que durante el siglo XVI, en ese lugar, no existió sino una modesta capilla donde se veneraba la imagen. No fue, sino en el siglo XVII cuando se construyó un edificio más importante que, a su vez, se reemplazó por otro más suntuoso. ${ }^{20} \mathrm{La}$ popularidad del culto era tal a fines de dicha centuria que resultó indispensable levantar otro, encomendándose la obra al arquitecto Pedro de Arrieta. ${ }^{21}$

La intensidad del culto opacó, por así decirlo, el de las otras devociones marianas. Tal vez a eso se deba la casi nula representación de esos baluartes mexicanos en la plástica novohispana. Visto así el problema, la representación de dicha advocaciones resulta por demás novedosa; tal como trataremos de mostrat enseguida.

La imagen de Nuestra Señora de la Piedad reproduce el original que se conservaba en el santuario, aunque el anónimo pintor dio mayor horizontalidad a la composición para lograr una especie de contrapunto con

18 Lauro Rosell en su obra Las iglesias de México, p. 38, al hablar de la iglesia de Jesús Nazareno de la ciudad de México, asienta: "Consérvase un altar dedicado al culto de nuestra Señora de la Bala, llamada así a causa de una curiosa leyenda. La escultura que representaba a la Virgen, fue robada de ese altar el día 22 de junio de 1901, ignorándose hasta ahora su paradero". El autor no especifica si se trata de la imagen venerada antes en la iglesia de San Lázaro o bien, de otra con el mismo nombre. Agradezco esta información a mi alumna la señora Magali Sche-

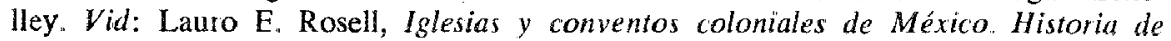
cada uno de los que existen en la Ciudad de México, 2a. ed, México, Ed. Patria, 1961.

19 Francisco de la Maza, op. cit. Edmundo G'Gorman, Destierro de Sombras. Luz en el origen de la imagen y culto de Nuestra Señora de Guadalupe del Tepeyac, México, UNAM, Instituto de Investigaciones Históricas, 1986, 306 p. Serie Historia Novohispana 36.

20 Sobre el santuario del siglo XVII puede consultarse el artículo de Efraín Cas. tro Morales, "El santuario de Guadalupe de México en el siglo XVIT". Retablo Barroco a la Memoria de Francisco de la Maza, México, UNAM, Instituto de Investigaciones Estéticas, 1974, pp 67.77.

21 Datos muy importantes sobre el santuario en el siglo XVIII aparecen en la monografía escrita por Delfina E. López Sarrenalangue, Una villa mexicana en el sgglo XVIII. México, Imprenta Universitaria, 1957, 34 p., ils. 
DOI: http://dx.doi.org/10.22201/iie.18703062e.1989.60.1535

1. Anónimo, Guadalupana con las cuatro apariciones y los baluartes de México. Pinacoteca Virreinal de San Diego, México, D. F.

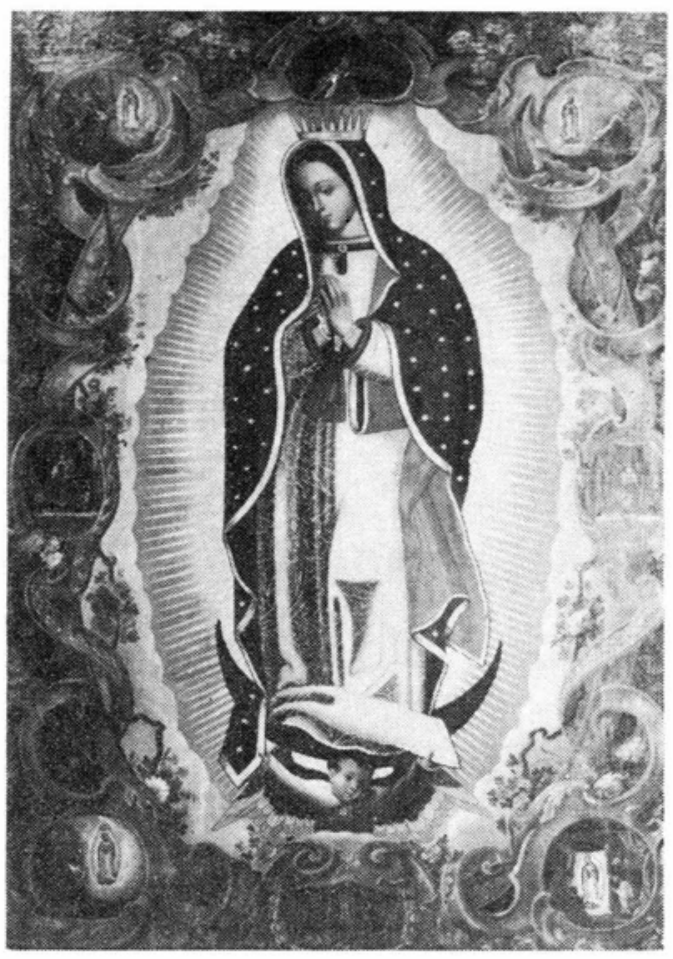

2. Baltasar de Echave Orio, Guadalupana. Col. Particular, México, D. F.

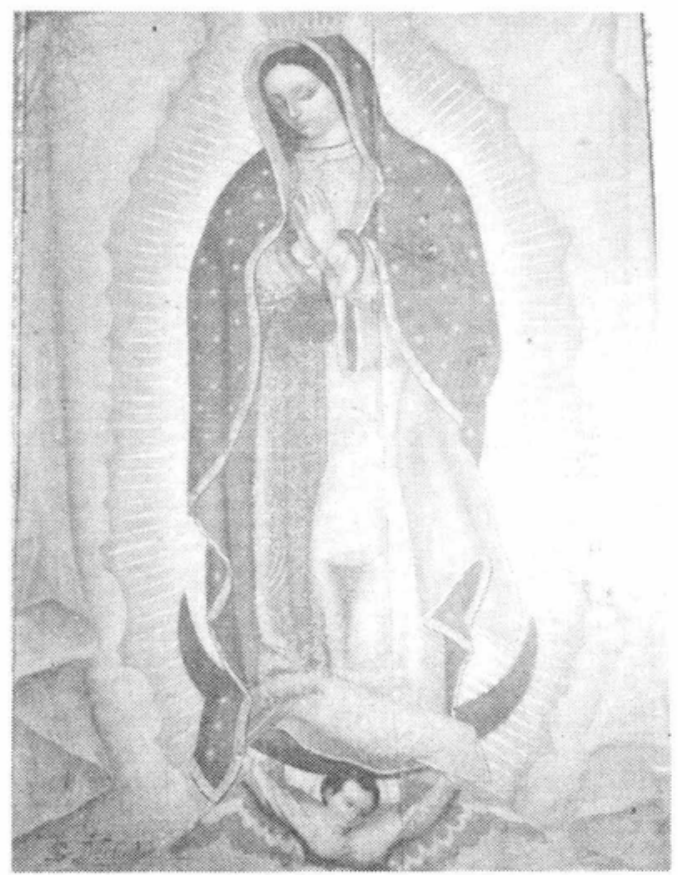


DOI: http://dx.doi.org/10.22201/iie.18703062e.1989.60.1535

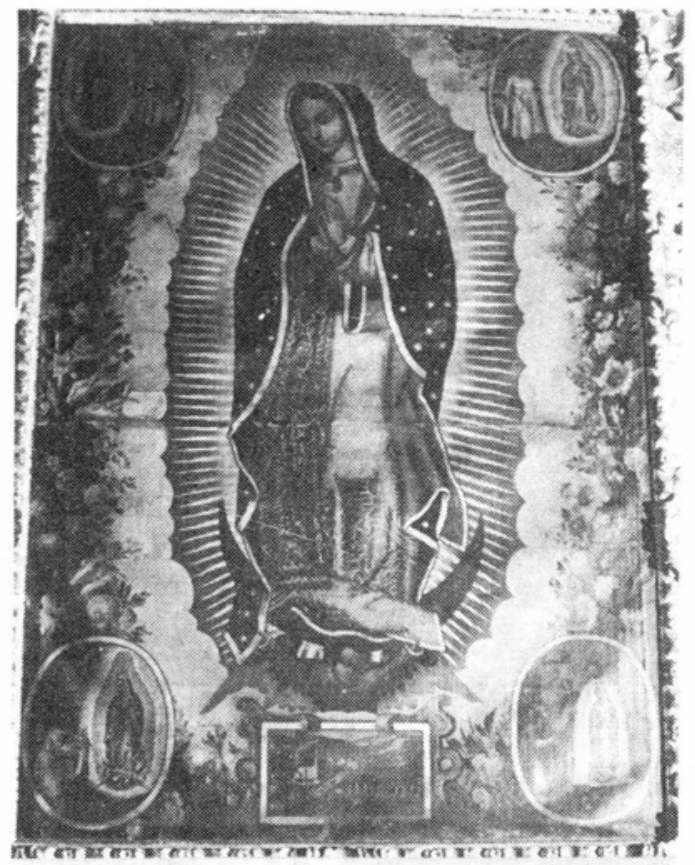

3. Juan Correa, Guadalupana. Iglesia de San Leandro, Sevilla.

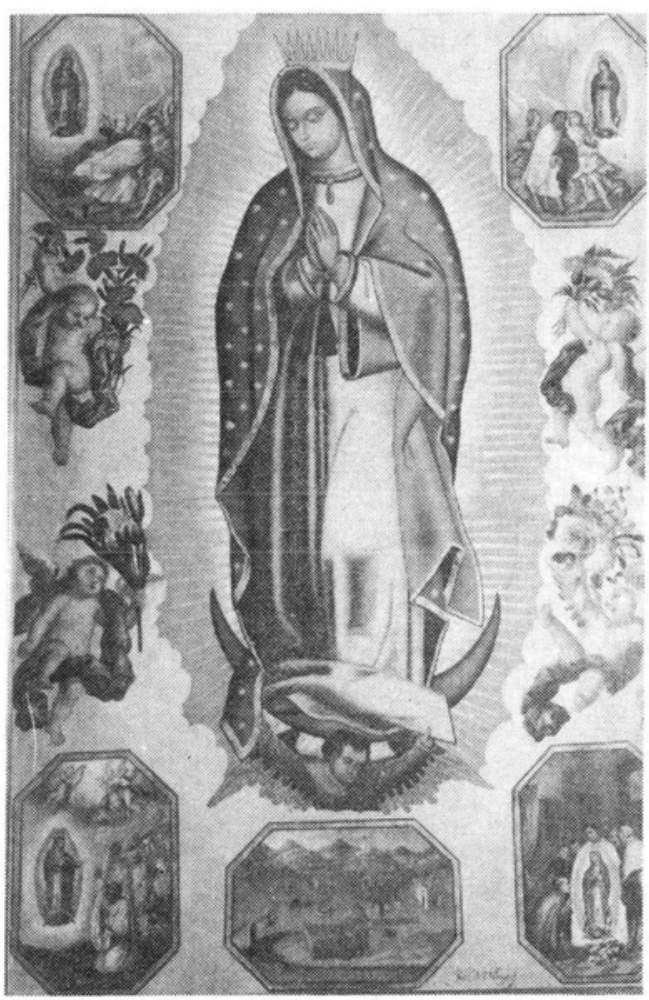

4. Juan de Villegas, Guadalupana. Museo de América, Madrid. 
DOI: http://dx.doi.org/10.22201/iie.18703062e.1989.60.1535

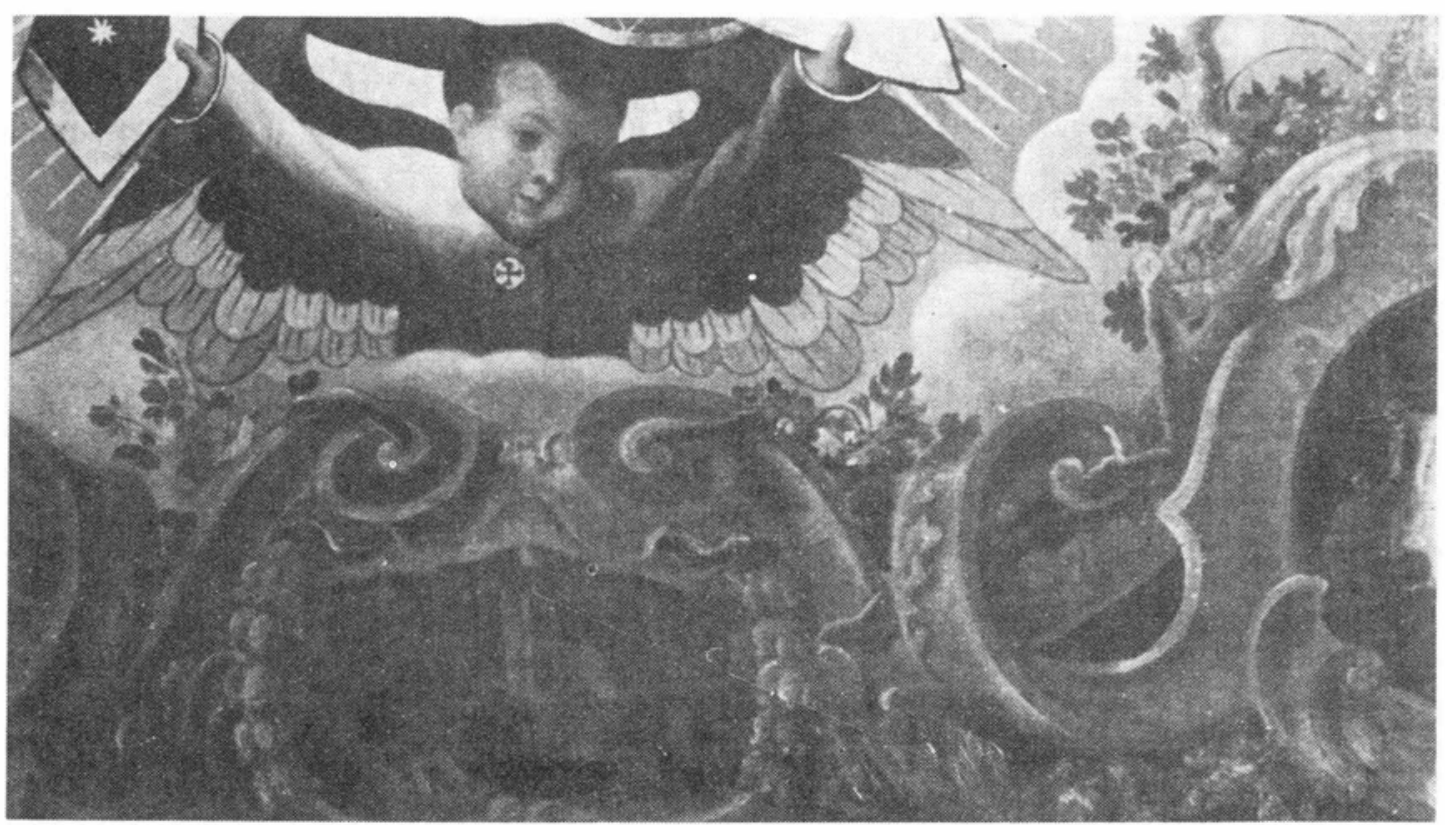

5. Anónimo, Guadalupana con los baluartes de México. Pormenor.

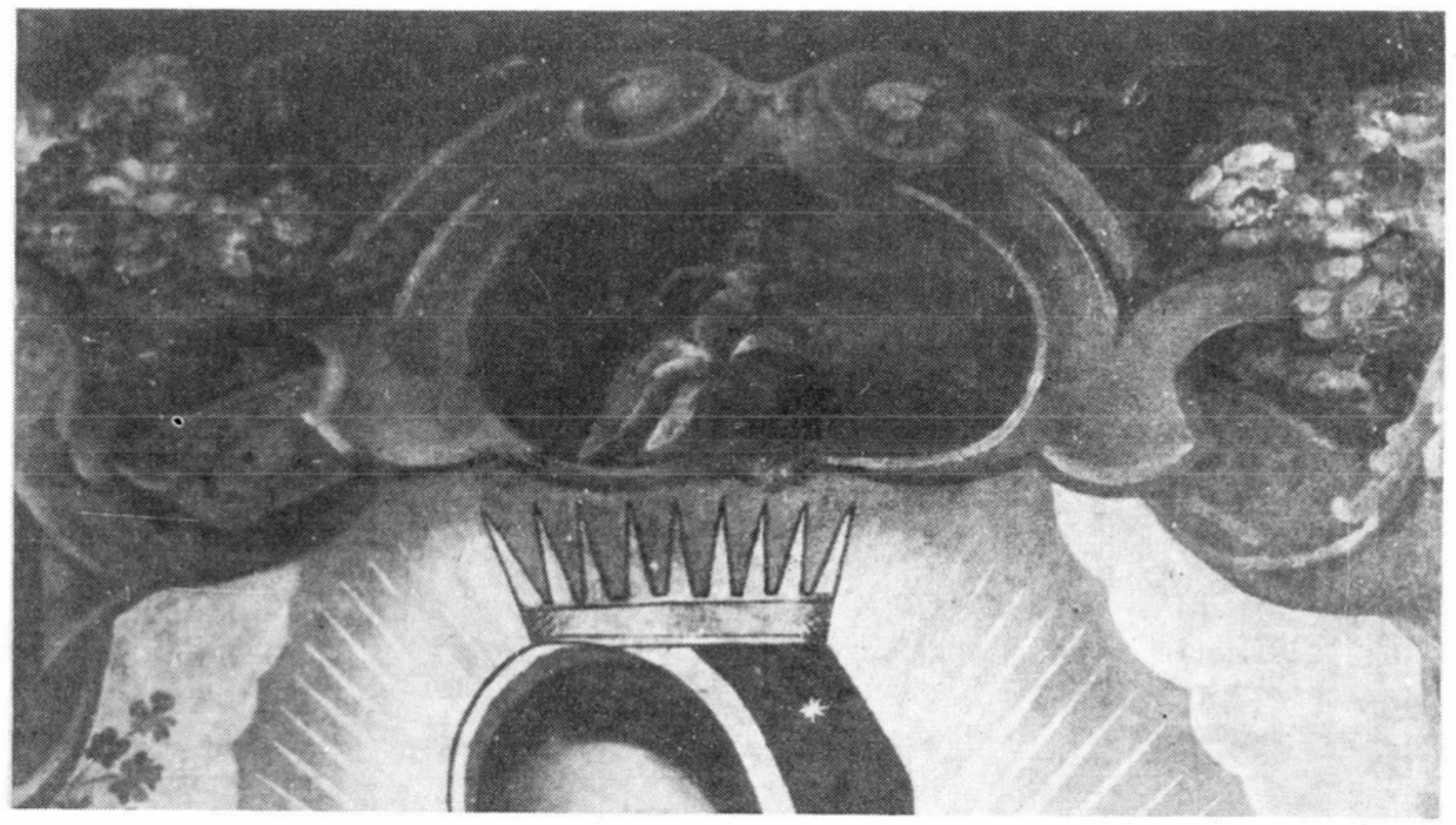

6. Anónimo, Guadalupana con los baluartes de México. Pormenor. 
DOI: http://dx.doi.org/10.22201/iie.18703062e.1989.60.1535

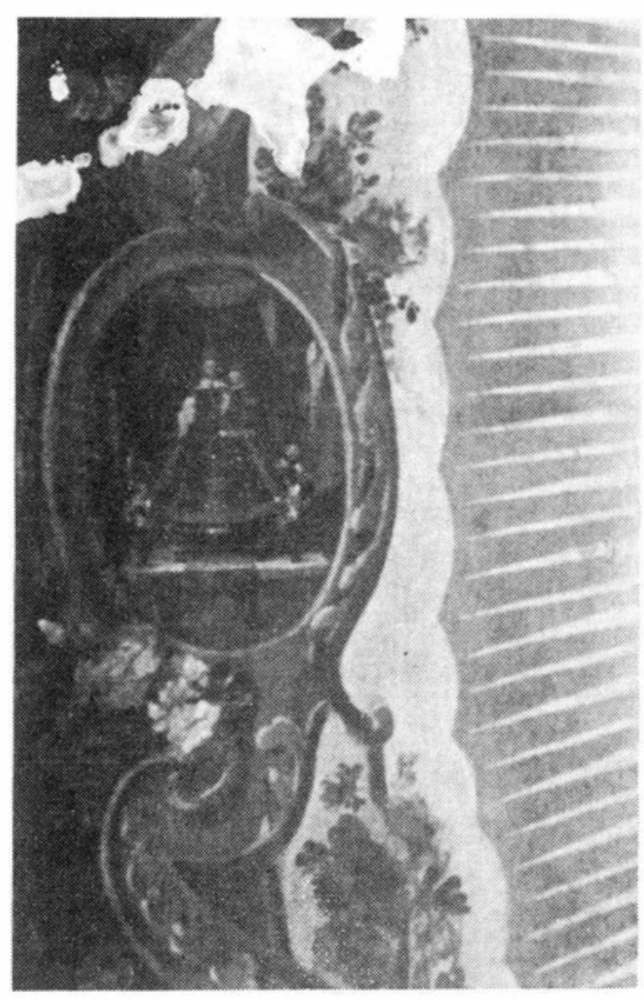

7. Anónimo, Guadalupana con los baluartes de México. Pormenor.

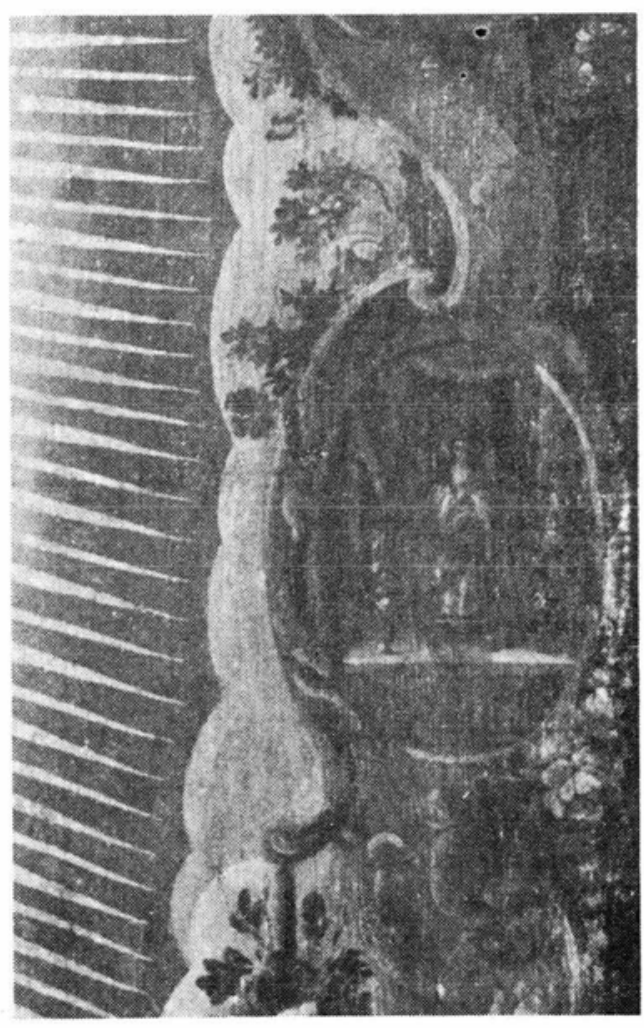

8. Anónimo, Guadalupana con los baluartes. Pormenor. 
la vista del santuario, en la parte baja. En cambio a la Virgen de los Remedios y a la de la Bala, y dado que el lienzo implicaba acentuada verticalidad, optó por enmarcarlas en sendos óvalos, con idéntica solución: una mesa de altar sobre la que están las imágenes, flanqueadas por floreros y el fondo lo constituye un cortinaje casi con el mismo tipo de pliegues en ambos casos. Las dos vírgenes aparecen vestidas, "al modo barroco"; sólo que la de los Remedios lleva amplio vestido, en su brazo izquierdo sostiene al Niño y con la mano derecha empuña un cetro. (Fig. 7). Esta manera de representarla coincide con las que en el siglo anterior pintó Juan Correa y que se conservan en España; también guarda similitud con otra de fines del siglo XVII y que adorna la sacristía del santuario. ${ }^{22}$ A la Virgen de la Bala que, como ya se indicó, era de bulto, la pintó vestida y quizá el rasgo más distintivo en esta representación sea el que guarda gran semejanza con otras representaciones de la Inmaculada Concepción. (Fig. 8).

Por lo que se refiere a la representación del santuario diremos que no difiere de otras que aparecen en decenas de pinturas guadalupanas de la época. Se trata de un paisaje urbano convencional, en el que destacan la basílica, la capilla del Cerrito y otras construcciones, sin que pueda precisarse de cuáles se trata.

\section{Conclusión}

Líneas atrás hacíamos notar que, independientemente del análisis plástico e iconográfico que pueda hacerse de las imágenes que integran esta composición, su estudio debe llevarse a cabo como una totalidad. Sobre todo si intentamos captar el posible significado que el cuadro tuvo en su tiempo. En ese sentido creemos que la lectura de la obra debe hacerse tomando en cuenta, en primer lugar, la imagen central: la Virgen de Guadalupe, como alfa y omega del culto mariano imperante en la Nueva España durante el siglo XVIIII. Enseguida cabe reparar en las cuatro apariciones puesto que, de alguna manera, confirmaban - desde el punto de vista plástico- lo que la tradición piadosa daba como un hecho real; la aparición de la Virgen a Juan Diego en la antigua Tepeaquilla. El esfuerzo de los "evangelistas de Guadalupe" - tal como designó Francisco

22 Elisa Vargas Lugo, José Guadalupe Victoria et al, Juan Correa. Su vida y su obra, México, UNAM, Instituto de Investigaciones Estéticas, 1985, Vol. II, Segunda Parte, pp. 216-218. 
de la Maza a los cuatro escritores criollos empeñados en "escribir la verdadera historia de las apariciones"- fue interpretado con ese recurso plástico por los pintores novohispanos quienes, con mayor o menor capacidad expresiva, lo plasmaron en sus lienzos. De esa manera, pensamos, reforzaban la presencia de María.

Incluir la vista del santuario enriquecía el aspecto formal de los lienzos guadalupanos. Pero no debe desecharse la idea de que, detrás de su representación, había un mensaje más profundo para los criollos novohispanos. Es decir que plásticamente deseaban hacer patente el hecho de haber cumplido con uno de los deseos - acaso el principal- de la Virgen, expresado claramente a Juan Diego: que se le erigiera un santuario donde brindaría consuelo y ayuda a cuantos acudieran a ella. Y si bien al principio tal deseo no fue cumplido, andando el tiempo los habitantes del virreinato contribuyeron, de una u otra manera, a la construcción del edificio que albergaría al ayate juandieguino. No obstante, en la mayoría de la producción pictórica guadalupana no se llegó a representar "fielmente" dicho paisaje urbano; salvo contadas excepciones, como es el enorme lienzo conservado en una colección particular de la ciudad de Madrid. ${ }^{23}$ Pero lo importante era dejar constancia del esfuerzo económico desplegado para erigir el baluarte mariano más importante del reino.

Sin embargo, los elementos iconográficos más significativos en la obra estudiada son las imágenes que aluden a los otros tres baluartes marianos que protegian a la ciudad. Observando el lienzo con detenimiento nos damos cuenta de que esas imágenes integran un cuadrado en el que se inscribe otra forma no menos simbólica: el círculo; en el cual se aloja la guadalupana, centro del culto mariano en la Nueva España de la segunda mitad del siglo XVIII.

Planteado así el problema, vale la pena hacer una última reflexión sobre el autor intelectual de esta composición. ¿Fue un pintor cualquiera el que la ideó? ¿Acaso sólo se atuvo a las indicaciones de un religioso? Asunto que tal vez nunca sabremos con certeza; pero eso no es razón para dejar de suponer que esta pintura se nos revela como un singular ejemplo de la piedad guadalupana; que si bien no era igual en todos los

23 Se trata del enorme lienzo pintado por José Arellano conocido como Procesión de la Virgen de Guadalupe. Vid. Manuel Ortiz Vaquero, "Pintura Guadalupana, tres ejemplos." Guadalupana de 1606, por Baltazar de Echave Orio. Procesión de la Virgen de Guadalupe en el siglo XVIII por José Arellano. Traslado de la imagen de la Virgen de Guadalupe a la primera ermita y primer milagro, anónimo". Imágenes Guadalupanas. México, Centro Cultural Arte Contemporáneo, TELEVISA, 1987, pp. 11-42. El cuadro aparece reproducido en la p. 35. 
DOI: http://dx.doi.org/10.22201/iie.18703062e.1989.60.1535

grupos que integraban la sociedad novohispana, fue sentida, entendida y manifestada de diversas maneras, siendo este lienzo una prueba contundente de tal aseveración. 